\title{
Molecular biology enjoys double celebration
}

Markus Wagner

The club of life scientists launched by nuclear physicist-turned-biologist Leo Szilard this week celebrates the fortieth anniversary of its transformation into EMBO, the European Molecular Biology Organization.

At the same time it celebrates the thirtieth anniversary of EMBO's most visible manifestation - the European Molecular Biology Laboratory (EMBL).

The celebrations are not ostentatious - a glass of champagne, a symposium. EMBO and EMBL, both based in Heidelberg, Germany, have gained status in the past ten years, but the financial temperature has always been chilly. At a time when the needs of molecular biology have grown, particularly for computational support to make sense of genomic data, funding has followed only grudgingly.

Despite such reluctance, EMBO, which runs a prestigious club of EMBO fellows as well as select meetings, has increased its modest budget by half in the past decade, allowing it to broaden its scope. This week it announced plans to extend its activities in central eastern Europe in the form of 'installation grants' to help young scientists set up their first lab. To begin with, this initiative is being financed by the Howard Hughes Medical Institute.
EMBL, with its extensive infrastructure and 1,300 staff based at Heidelberg and four outstations in different countries, has always been a more expensive proposition. Over the years, it has fought, and mostly won, hard battles with the governments of the 17 member states that finance it. Its budget has more than quadrupled since 1981. The fights have often been bitter — in the early 1990s, Italy, a major funder, threatened to pull out if EMBL did not create special labs in Italy; the lab complied. But EMBL is now the most cited molecular biology research institution outside the United States.

Fleeing the Cuban missile crisis in 1962, Szilard found refuge at CERN, the European particle-physics laboratory in Geneva, which celebrated its fiftieth anniversary this year (see Nature 430, 824-827; 2004). CERN had been created to counteract the drain of nuclear scientists to the United States, and to promote international cohesion in postwar Europe.

Szilard envisioned that EMBO would do the same for biologists. But many critics argued that funding of a bricks-and-mortar European institute would only take money away from national projects. They complained that while CERN's huge particle accelerators could not be afforded by one country alone, molecular biology was cheap and could be done at home. It is no longer cheap - and its basic economic value is no longer in doubt. Critics are quieter these days.

\section{Stalemate over fusion project threatens to provoke split}

\section{Jim Giles}

The European Union (EU) is considering going it alone with plans to build ITER, an international attempt to develop fusion as an energy source.

Research ministers from EU member states will discuss plans to build the $€ 4$.7-billion (US\$6.1-billion) device without the help of international partners when they meet in Brussels on 25 and 26 November. Officials at the European Commission, the EU's executive arm, stress that this is a fall-back position should arguments over where to site the reactor not be resolved.

Hopes for a resolution are not high. France and Japan have both proposed sites for the reactor, which will attempt to create fusion energy by heating a plasma constrained in a magnetic field. The proposals are considered to have equal merit, and parties have been deadlocked for more than a year. European nations want the reactor to be based at Cadarache in France; the United States and South Korea favour the Japanese site at Rokkasho.

The latest international meeting, held on 8 and 9 November in Vienna, ended yet again without decision. The dispute attracted attention when the Reuters news agency reported that an EU official had said that Japan was going to back the French site. Japanese officials angrily denied the story and, according to a European source, stiffened their resolve not to back down.

EU ministers will now consider an analysis of their ability to host the project without Japan, South Korea and the United States. That trio are currently offering to provide $30-40 \%$ of the construction and launch costs, says Fabio Fabbi, commission spokesman for research. He says the commission will consider asking for extra funding from France, Russia and China, or find cheaper ways of building the reactor.
"For both financial and technological reasons, I think that would be very difficult," says Takahiro Hayashi, deputy director of Japan's office of fusion research. "This has always been a project based on international cooperation. Giving up on that would be deplorable."

EU ministers may decide to continue negotiations. Details of the Vienna talks have not been revealed, but it is believed that Japan was offered a deal under which it would end its bid to be host in return for a greater role in other research projects associated with ITER.

Those involved in the decision-making all say they would prefer a full international programme, but stress that talks cannot continue indefinitely. One official, who asked not to be named, points out that ITER currently has backing from the highest political level of the union. "But in another year nobody can say what the level of support will be," the official adds. 